\title{
Deleted in Colorectal Carcinoma and Differentially Expressed Integrins Mediate the Directional Migration of Neural Precursors in the Rostral Migratory Stream
}

\author{
Shin-ichi Murase and Alan F. Horwitz \\ Department of Cell Biology, University of Virginia School of Medicine, Charlottesville, Virginia 22908
}

\begin{abstract}
Precursors of the olfactory interneurons migrate from the subventricular zone via the rostral migratory stream (RMS). To investigate the molecular mechanisms by which RMS cells migrate, we used a slice preparation, which allows the migrating cells to be imaged at very high temporal and spatial resolution in the presence of added inhibitors. Using immunohistochemistry, we first determined that the $\alpha 1-, \beta 8$-, and $\beta 1$-integrin subunits and the $\alpha 5$ - and $\gamma 1$-laminin subunits are expressed during embryonic day 16 to the early postnatal stage. During early postnatal days, $\alpha v$ - and $\beta 6$-integrins appeared, and their expression persisted throughout adulthood. The migrating cells also expressed the netrin receptors neogenin and Deleted in Colorectal Carcinoma (DCC). Netrin-1 is expressed in olfactory
\end{abstract}

mitral cells. Anti-integrin antibodies inhibited the production of protrusions as well as cellular translocation. In contrast, antiDCC antibodies primarily altered the direction of the protrusions; consequently, the migration was no longer unidirectional, and the speed was reduced. Thus, the interaction of DCC, possibly through an interaction with netrin-1, contributes to the direction of migration by regulating the formation of directed protrusions. In contrast, the integrins function in production of protrusions and cellular translocation, with different integrins participating at different developmental stages.

Key words: chemoattraction; neural cell adhesion molecule; slice culture; video microscopy; radial glia; time-lapse recording; polysialic acid
In the rodent brain, the subventricular zone (SVZ) is a mitotically active region that surrounds the ependymal wall of the lateral ventricle and is characterized by a high cell density (Allen 1912; Messier et al., 1958; Bryans, 1959; Boulder Committee, 1970). Precursors of the olfactory interneurons generated at the SVZ migrate tangentially, via the restricted route called the rostral migratory stream (RMS), to the olfactory bulb, where they then differentiate into periglomerular cells and granule cells (Altman, 1969; Luskin, 1993; Lois and Alvarez-Buylla, 1994). This migration does not end when the olfactory bulb reaches adult size; rather, it continues in the adult, and it is neither gliophilic nor axonophilic, as reported in many other brain regions (Rakic, 1971; Hynes et al., 1986; Lois and Alvarez-Buylla, 1994). The mechanism of this migration is unclear. The polysialylated form of neural cell adhesion molecule (PSA-N-CAM) appears to play an important role, on the basis of studies using knock-out mice (Tomasiewicz et al., 1993; Cremer et al., 1994), enzymatic removal of polysialic acid (PSA) (Ono et al., 1994), and transplantation (Hu et al., 1996). One plausible explanation for the influence of PSA-N-CAM on the migration is that the PSA moiety reduces the adhesive properties of N-CAM (Hoffman and Edelman, 1983; Sadoul et al., 1983; Rutishauser et al., 1985) and allows the cells to translocate in the RMS. The absence of PSA, in contrast, causes the cells to adhere more strongly and thus inhibits migration. Although the above studies support a role for

Received Sept. 5, 2001; revised Feb. 6, 2002; accepted Feb. 6, 2002.

This work was supported by National Institutes of Health Grants GM23244 and GM53905 (A.F.H.), by the Cell Migration Consortium (A.F.H.), and by a Human Frontier Science Program Organization award (S.M.). We thank Dr. J. H. Miner, Dr. G. Rougon, and Dr. K. Sekiguchi for providing antibodies.

Correspondence should be addressed to Shin-ichi Murase, Department of Cell Biology, University of Virginia School of Medicine, P.O. Box 800732, Charlottesville, VA 22908. E-mail: sm4fh@virginia.edu.

Copyright (C) 2002 Society for Neuroscience $\quad 0270-6474 / 02 / 223568-12 \$ 15.00 / 0$
PSA-N-CAM, other molecules likely contribute to migration along the RMS. For example, the alterations in migration are only partial in mice with an inactive N-CAM gene (Chazal et al., 2000), suggesting that additional mechanisms contribute to the directed migration. Interestingly, the migrating neuronal precursors in the adult have the appearance of chains, which coalesce to form the RMS (Lois et al., 1996), whereas those in the neonates form thicker streams more akin to intertwined ropes than to chains (Kishi, 1987; Kishi et al., 1990). Electron microscopic analyses in the adults show that glial cells and their processes cover the migrating cells (Jankovski and Sotelo, 1996; Lois et al., 1996) and form the walls of longitudinally arranged canals commonly referred to as "glial tubes" (Peretto et al., 1997). In the neonatal RMS, however, the migrating precursors do not appear to be surrounded by such glial processes and instead migrate through a large extracellular space (Kishi et al., 1990). Thus, it seems likely that the molecular mechanisms underlying migrations along the RMS differ in adults and neonates.

In the present study, we used slice technology to visualize the nature of RMS migrations at high spatial and temporal resolution (Wu et al., 1999; Knight et al., 2000). We also identified additional adhesion molecules, extracellular matrices, and chemoattractive factors that are expressed in the RMS during development. We found that six integrin subunits and the receptor for netrins were differentially expressed and contributed to migration. The integrins provide traction for cellular translocation, whereas the netrins appear to contribute to the direction of the migrations.

\section{MATERIALS AND METHODS}

Immunohistochemistry. Wild-type mice (ICR or CD-1 strains) and rats (SD strain) were purchased from Hilltop Lab Animals, Inc. (Scottdale, PA) and housed using a $12 \mathrm{hr}$ light/dark cycle. Heterozygotes of N-CAM knock-out mice (Cremer et al., 1994) were purchased from The Jackson Laboratory (Bar Harbor, ME). Homozygotes were obtained by breeding 
the heterozygotes, and brain tissues of the homozygotes were used to confirm the specificity of anti-N-CAM and anti-PSA monoclonal antibodies. Fifteen homozygous, 30 heterozygous, and 15 wild-type mice were characterized. For immunostaining, the mice or rats were anesthetized with halothane. To obtain the brains of fetuses, deep anesthesia was used on the pregnant mice, and the abdominal cavity was opened to remove the fetuses. The mother's diaphragm was cut to ensure that she had been killed. The embryos still under the crossover anesthesia were perfused through the aorta with fixatives consisting of either $4 \%$ paraformaldehyde and $0.1 \mathrm{~m}$ phosphate buffer or acid-ethanol $(5 \%$ acetic acid in ethanol). The postnatal mice were anesthetized with halothane and perfused through the aorta with the above fixatives. The dissected brains were immersed in $20 \%$ sucrose and PBS, frozen in powdered dry ice, and embedded in Tissue-Tek OCT compound (Miles, Elkhart, IN). Parasagittal or horizontal sections $(20 \mu \mathrm{m})$ of brains were cut using a cryostat and mounted on silane-coated slides. For immunoperoxidase staining, sections were treated with primary antibodies for $42 \mathrm{hr}$ at $4^{\circ} \mathrm{C}$ and then incubated with peroxidase-conjugated secondary antibodies for $2 \mathrm{hr}$ at room temperature. The immune complexes on the sections were detected using a peroxidase substrate consisting of diaminobenzidine-tetrahydrochloride as described previously (Murase, 1995).

Antibodies. Anti- $\alpha 1$-integrin [antibody (AB) 1934; Chemicon, Temecula, $\mathrm{CA}]$, anti- $\alpha \mathrm{v}$-integrin (AB1930; Chemicon), and anti- $\beta 1$-integrin (AB1938; Chemicon) antibodies were assayed for specificity by preabsorption using the peptides against which the antibodies were raised and Western blotting as described previously (Murase and Hayashi, 1996, $1998 \mathrm{a}, \mathrm{b})$. The function-blocking anti- $\beta 1$-integrin rat monoclonal antibody (clone 9EG7) was obtained from PharMingen (San Diego, CA); its specificity has been reported previously (Lenter et al., 1993; Lenter and Vestweber, 1994). The anti- $\alpha$ v-integrin (T-20), anti- $\beta 3$-integrin (C-20), anti- $\beta 6$-integrin (C-19 and $\mathrm{N}-20)$, and anti- $\beta 8$-integrin $(\mathrm{C}-19)$ and antineogenin (C-20) antibodies were obtained from Santa Cruz Biotechnology, (Santa Cruz, CA). The specificities of these antibodies for immunohistochemistry were verified by absorbing each primary antibody with 0.5 $\mathrm{mM}$ corresponding antigen-peptide solution overnight at $4^{\circ} \mathrm{C}$ before application to brain sections, which was then followed by the diaminobenzidine reaction. Other control experiments included omission of primary antibodies. Anti-tenascin-C rat monoclonal antibody (clone MTn-12) was obtained from Sigma (St. Louis, MO); its specificity and immunoreactivity in the forebrain have been reported previously (Aufderheide and Ekblom, 1988; Jankovski and Sotelo, 1996). The function-blocking antiDeleted in Colorectal Carcinoma (DCC; clone AF5, which was raised against the extracellular domain of DCC), anti-netrin-1 (PC364), and its control peptide were from Oncogene Research Products (Cambridge, MA); their immunoreactivities and the function-blocking activity of AF5 have been reported previously (Keino-Masu et al., 1996; Madison et al., 2000). Clone Men-B for PSA-N-CAM was a gift from G. Rougon (Centre National de la Recherche Scientifique, Marseille, France) (Rougon et al., 1986), anti- $\alpha 4$ - and $\alpha 5$-laminins were gifts from J. H. Miner (Washington University School of Medicine, St. Louis, MO) (Miner et al., 1997), and anti- $\gamma 2$-laminin was a gift from K. Sekiguchi (Osaka University, Osaka, Japan) (Fukushima et al., 1998). Clones 5A5 (PSA-N-CAM), AG1 and 5B8 (N-CAM), and 2E8 and D18 ( $\gamma 1$-laminin) were obtained from the Developmental Studies Hybridoma Bank, (DSHB), University of Iowa, Department of Biological Sciences (Iowa City, IA). Anti-collagen I (AB765), anti-collagen IV (AB756), antifibronectin (AB2033), anti-vitronectin (AB1903), anti- $\alpha 2$-integrin (AB1936), anti- $\alpha 3$-integrin (AB1920), anti- $\alpha 4$-integrin (AB1924), anti- $\alpha 5$ integrin (AB1928-P and AB1949), anti- $\alpha 6$ integrin [monoclonal AB (MAB) 1972 and clone GoH3], anti- $\beta 4$-integrin (AB1922), anti- $\beta 5$ integrin (AB1926), and anti- $\alpha 2$-laminin (MAB1922) were all obtained from Chemicon. Anti- $\beta 2$-laminin clones C4, D5, and D7 were from DSHB. Anti-adenosine A2B receptor (R-20), anti- $\alpha 1$-laminin (M-20), and anti- $\beta 1$ laminin (C-19) were obtained from Santa Cruz Biotechnology. These antibodies did not react with any cellular or extracellular components along the RMS (data not shown).

Preparation of brain slices. Slices were prepared from embryonic day 18 (E18) and postnatal day 0 (P0)-P16 mice using modifications of the methods of Stoppini et al. (1991) and Knight et al. (2000). For each individual experimental determination, two slices from each brain, at a minimum, were used, and the results were confirmed by at least two additional determinations. Slices that contained the entire migratory stream, which originated from the anterior portion of the SVZ (SVZa) and ended at the center of the olfactory bulb, were selected for further studies. The postnatal mice were anesthetized with halothane and decapitated. For fetal brains, the pregnant mice were deeply anesthetized, and the abdominal cavity was opened to remove the fetuses. The mother's diaphragm was cut to ensure that she had been killed. While still under crossover anesthesia, the fetuses were decapitated, and their brains were removed. The brains were placed into cell culture media 1 (CCM1) (Hyclone, Logan, UT) medium at $4^{\circ} \mathrm{C}$. The brains were then transferred into CCM1 or F-12 medium (Invitrogen, Rockville, MD) containing 5\% heat-inactivated horse serum (Sigma) and penicillin and streptomycin antibiotics (Sigma). They were then embedded CCM1 medium containing $8 \%$ agarose (Sigma type IX) and sliced into 200 $\mu \mathrm{m}$ parasagittal sections using a vibratome. The slices were cultured on a Millicell-CM membrane (Millipore, Bedford, MA) according to the method of Stoppini et al. (1991).

DiI labeling and time-lapse videomicrography. Small crystals of the lipophilic dye DiI (D-3911; Molecular Probes, Eugene, OR) were placed onto the SVZa, the RMS, or the central portion of the olfactory bulb of the slices using a microneedle (Fig. 1). Images were acquired using a Nikon IX-70 inverted microscope fitted with a cooled CCD camera (Photometrics CH250). The microscope was also equipped with a Ludl motorized XYZ stage and heating insert (Medical Systems Corp.). Electronic shutters regulated fluorescence illumination. Image acquisition and processing used Inovision software. After $5 \mathrm{hr}$ of incubation, a field in each slice was selected that retained good morphology and had fluorescently labeled (migrating) cells adjacent to the DiI crystals. In a typical experiment, nearly all of the DiI-treated slices displayed appropriate labeling. The slices were illuminated with either a mercury or halogen lamp. A tetramethyl rhodamine isothiocyanate filter cube was used to observe the DiI-labeled cells. Fluorescence images were recorded from multiple fields every $5 \mathrm{~min}$ using a $10 \times$ objective. Images were typically captured over $3-10 \mathrm{hr}$ using $0.015-0.20 \mathrm{sec}$ exposures. The time-lapse movies (available at www.jneurosci.org) were analyzed for cells that migrated to the olfactory bulb along the rostral migratory stream.

Function-blocking assays. The tissue slices that showed migrating cells labeled with DiI were selected and cultured in CCM1 medium containing function-blocking antibodies against $\alpha 1$-integrin (Mendrick et al., 1995), $\beta 1$-integrin (9EG7; Lenter et al., 1993; Lenter and Vestweber, 1994), $\alpha \mathrm{v}$-integrin (H9.2B8; Maxfield et al., 1989), $\beta 3$-integrin (2C9.G2; Frieser et al., 1996), or DCC (AF5; Keino-Masu et al., 1996). The function-blocking antibodies for integrins were purchased from PharMingen (San Diego, $\mathrm{CA}$ ), and the specificities and function-blocking activities of these are reported in the publications cited above. For negative controls, isotypecompatible antibodies, from a matched species, directed against keyhole limpet hemocyanin, and anti-trinitrophenol were used. MAB 5A5, an IgM directed against PSA (DSHB) was used at $10 \mu \mathrm{g} / \mathrm{ml}$ to assay the effect of PSA on migration in early postnatal mice, when PSA expression is very weak or not found. MAB 8D9, an anti-L1 MAB (DSHB), was used as a negative control for AF5. Anti-integrin and control antibodies were used at $20 \mu \mathrm{g} / \mathrm{ml}$, and anti-DCC and its control were used at $5 \mu \mathrm{g} / \mathrm{ml}$.

Migration parameters. The time-lapse movies were analyzed for migration speed and direction. The center of the soma of a migrating cell was traced at $5 \mathrm{~min}$ intervals, and the speed and direction of migration during the time-lapse recording were determined as described by Knight et al. (2000). Each value represents the mean \pm SD. Statistical analysis was performed by one-way ANOVA with Scheffé's multiple comparison procedure (significance of $p<0.01$ ).

\section{RESULTS}

\section{Expression of adhesion and guidance molecules in the RMS}

To determine the repertoire of molecules that contribute to the migration of neural precursors during different stages of development, we investigated the expression of two classes of adhesion molecules in the RMS of both embryos and adults. Figure $2 \mathrm{~A}$ shows a Nissl-stained sagittal section containing the entire route of the RMS in a P4 rat. PSA-N-CAM was reported previously to contribute to the migration of neural precursors in the RMS (Ono et al., 1994). Surprisingly, the expression of N-CAM and PSA in the RMS, as assayed by four independent monoclonal antibodies; e.g., the 5B8 and AG1 MABs, directed against N-CAM, and the 5A5 and Men-B MABs, directed against PSA epitopes, revealed only weak expression of N-CAM (Fig. 2B) and PSA (Fig. 2C) before $\mathrm{P} 4-\mathrm{P} 5$. In contrast, neurons and axons in the cerebral 
Figure 1. Experimental design for assays of cell migration in the RMS. Two hundredmicrometer-thick sagittal slices were cut from brains dissected from embryonic day 18 or postnatal day 0-16 mice using a vibratome. Slices containing the entire RMS were selected and placed on Millicell inserts in CCM1 medium containing HEPES and 5\% horse serum. Crystals of DiI were placed on the RMS using a microneedle. By selecting the position of the DiI crystals, migrating cells in every part of the RMS can be visualized. Time-lapse images of fluorescent cells were recorded over 3-10 hr using an inverted microscope.

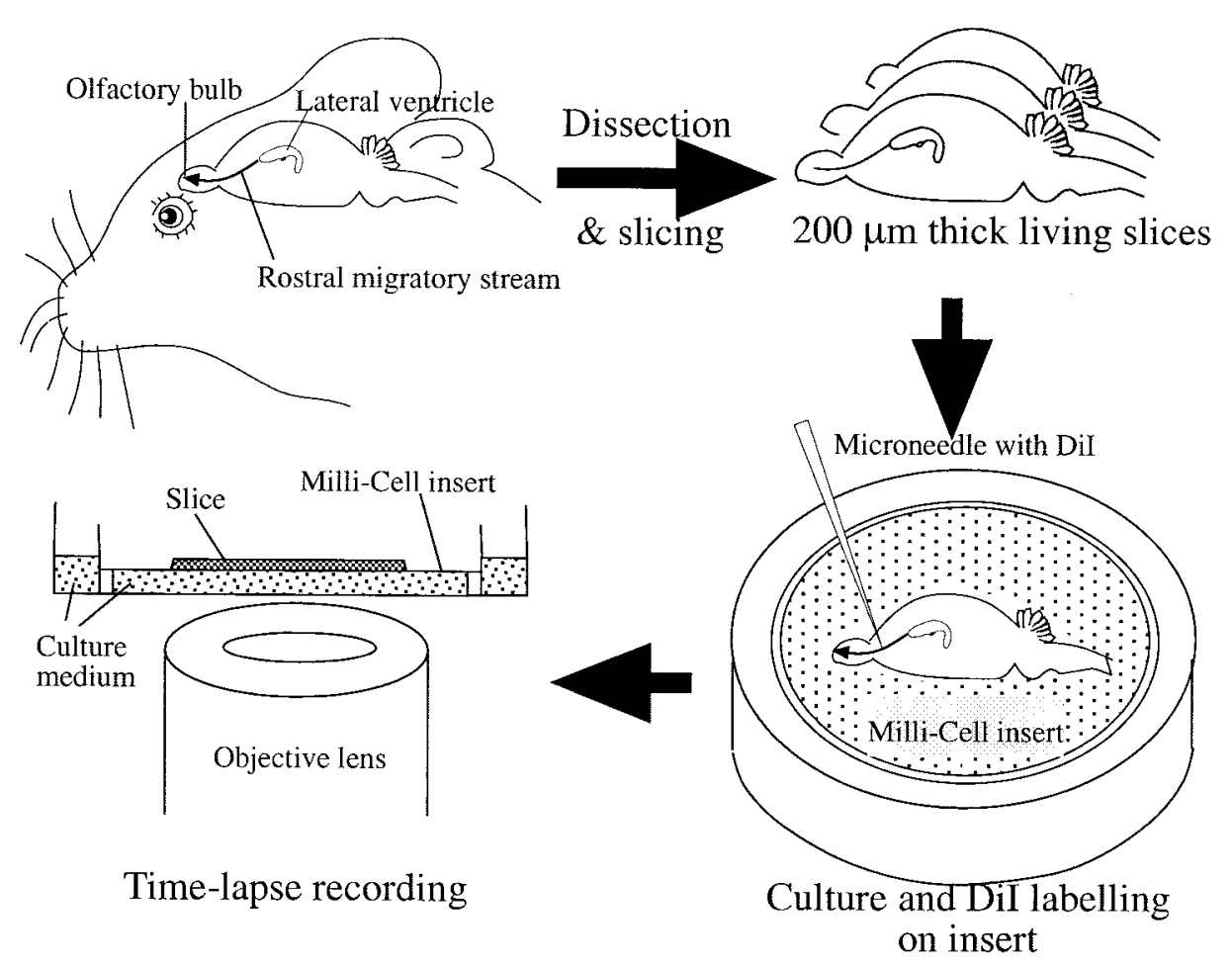

cortex, corpus callosum, olfactory tubercle, and caudate-putamen surrounding the RMS and SVZ were positive for N-CAM and PSA. The PSA immunoreactivity in the RMS peaked at $\sim$ P30 (Fig. 2D) at a level that persisted in the adult, whereas the region adjacent to the RMS showed very low immunoreactivity. These four MABs did not react with RMS and olfactory bulb sections from N-CAM knock-out homozygotes (data not shown).

Laminin, which supports migration of many neurons, is also expressed in the RMS and basement membranes of blood vessels. The $\alpha 5$ and $\gamma 1$ subunits were observed in a punctate pattern in the RMS during E16-E20 and E16-P4, respectively (Fig. 2E,F), whereas other laminin subunits, including $\alpha 1, \alpha 2, \alpha 4, \beta 1, \beta 2$, and $\gamma 2$, were not expressed detectably. Although most of the laminin immunoreactivity in the RMS was highly punctate, in some cases the staining tended to resemble cellular contours. However, we were unable to discern at this resolution whether the staining was intracellular or extracellular. Collagen type I, fibronectin, and vitronectin were not prominently expressed along the RMS but were seen in blood vessels. Tenascin-C was also observed along the RMS, as reported previously (Jankovski and Sotelo, 1996; Thomas et al., 1996; data not shown).

These data suggest that other adhesion molecules, in addition to N-CAM, might participate in RMS migrations, especially at relatively early developmental stages. Therefore, we assayed for the expression pattern of integrins, because they can mediate interactions of cells with laminin. Six integrin subunits were expressed on putative migratory cells in the RMS: $\alpha 1, \alpha \mathrm{v}, \beta 1, \beta 3$, $\beta 6$, and $\beta 8$. Interestingly, the relative expression of these integrins changed during development. They were rarely found in cells migrating radially from the center of the olfactory bulb, suggesting that the integrins mainly function in the tangential migrations. The glial tube surrounding the RMS also did not express these integrins. The $\alpha 1$ and $\beta 8$ subunits appeared initially in the RMS (Figs. $3 A, B$ ); their expression was followed by expression of the $\beta 1$ subunit (Fig. $3 C$ ). Expression of the $\alpha 1$ and $\beta 8$ subunits diminished at P3-P4, coinciding with the expression of the $\alpha \mathrm{v}$ subunit, which began to appear at $\sim \mathrm{P} 2-\mathrm{P} 3$ and continued into the adult (Fig. $3 D$ ). The $\beta 1$ subunit was expressed until P10, whereas the $\beta 6$ subunit appeared at $\sim \mathrm{P} 10$ and continued to be expressed in the adult (Fig. $3 E$ ). The $\beta 3$ subunit appeared in the adult RMS beginning at P28 and then persisted (Fig. $3 F$ ). These dynamic integrin expression patterns are summarized in Figure 4.

\section{Visualizing RMS migrations}

The presence of the integrins on migrating cells prompted us to use a preparation with which we could visualize migration at high temporal and spatial resolution and assay the effects of antibody reagents for their effects on migration in the RMS. For this, we prepared $200-\mu \mathrm{m}$-thick slices from neonatal mouse forebrains, which were embedded in agarose gels and sliced using a vibratome (Fig. 1). The viability of the cells in the slices was assayed by trypan blue exclusion. Dye-incorporating dead cells were rarely found in the RMS or other brain regions (data not shown) up to P16, although they were common in slices from older brains (>P18). Therefore, we only examined slices from P0-P16 mice. The migrating cells were labeled by placing a small crystal of DiI on the slice in the anterior region of the SVZ or RMS.

Actively migrating cells labeled by DiI were found in the RMS during the younger neonatal stages that we studied. As shown in Figure $5 A$ (collage and Movie 1, available at www.jneurosci.org), the overall direction of migration was highly persistent and directed toward the olfactory bulb (Fig. $5 B$ ). No labeled cells were observed to migrate into regions surrounding the RMS. The migrating cells were highly polarized, with long leading processes and relatively small somata. This morphology is similar to that observed by silver impregnation (Kishi, 1987). Once at the olfactory bulb target, the cells tended to meander without clear direction or substantial net movement (Movie 4, supplemental data, available at www.jneurosci.org). Thus, the slices appear to be viable and to reflect the migrations present in the native brain. 

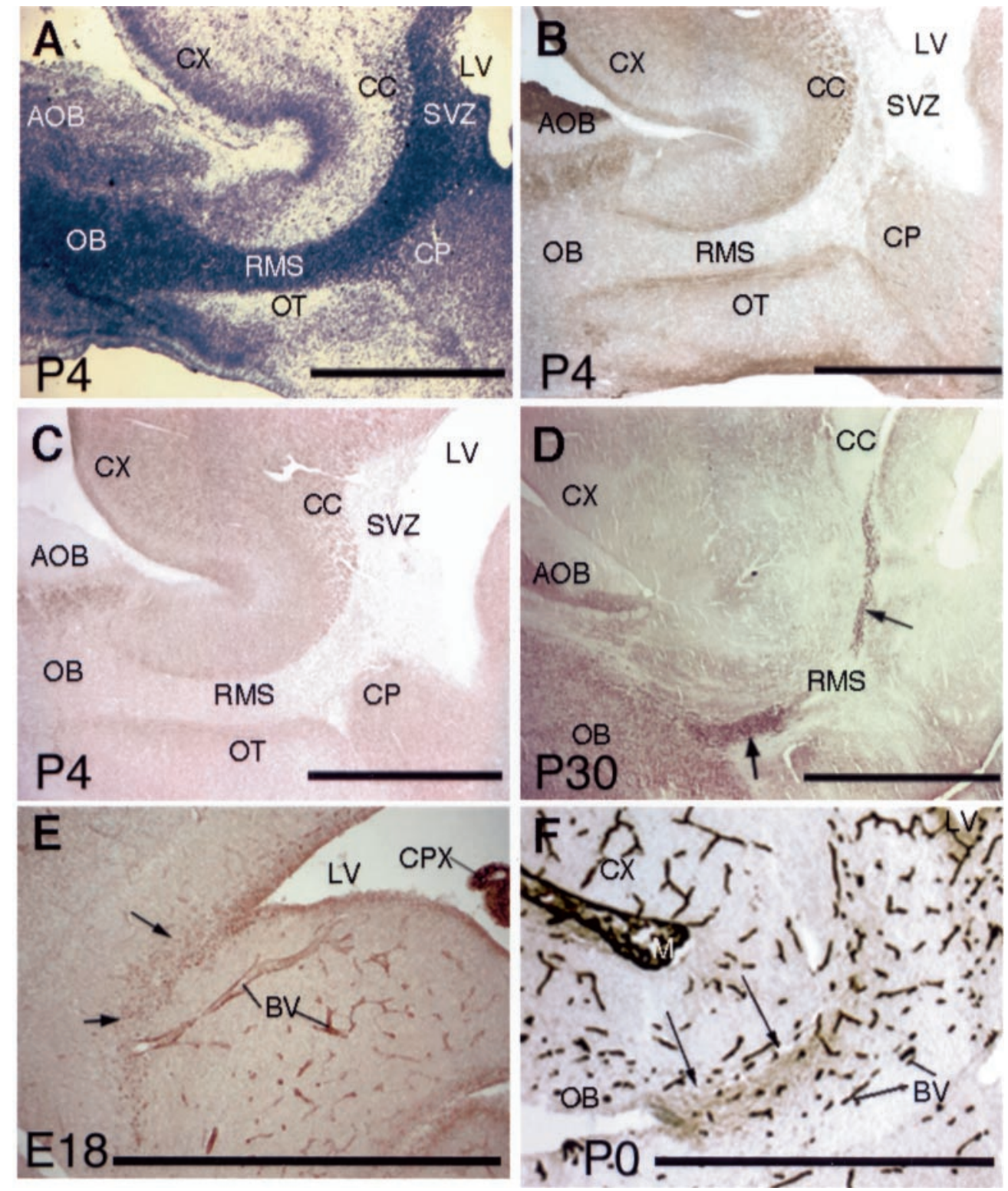

Figure 2. N-CAM, PSA, and laminin expression in the rostral migratory stream. $A$, Nissl staining of a sagittal section from a postnatal day 4 rat forebrain. The RMS, which is characterized by a high cellular density, begins at the anterior portion of the SVZ and ends at the center of the olfactory bulb $(O B) . B$, $C$, N-CAM and PSA in the RMS of early postnates. $B$ and $C$ are adjacent sections from a $\mathrm{P} 4$ rat forebrain that are stained with anti-N-CAM (clone 5B8) and anti-PSA (clone MenB) MABs, respectively. The SVZ and the RMS stain very weakly, whereas the borders of the RMS show strong staining. $D$, PSA immunostaining of a P30 mouse forebrain. In contrast to weak expression of PSA in P4 RMS shown in $C$, PSA is expressed strongly in the RMS (arrows) and the olfactory bulb $(O B) . E, \alpha 5$ subunit of laminin in the RMS (arrows) from an embryonic day 18 mouse shows punctate staining. Relatively strong staining is also seen in the choroid plexus $(C P X)$ of the lateral ventricle $(L V)$ and blood vessels $(B V) . F, \gamma 1-$ Laminin is expressed in the RMS (arrows) from a P0 rat brain. Blood vessels $(B V)$ and the meninges $(M)$ are also stained. Scale bars: $A-D, F, 1 \mathrm{~mm} ; E, 50$ $\mu \mathrm{m}$. $A O B$, Accessory olfactory bulb; $C C$, corpus callosum; $C P$, caudate-putamen; $C X$, cerebral cortex; $O T$, olfactory tubercle.
Some parameters characterizing the migration were quantified. The average speeds of migration in P3, P5, and P12 control slices were $98 \pm 26,85 \pm 19$, and $94 \pm 20 \mu \mathrm{m} / \mathrm{hr}$, respectively. These values did not show any statistically significant differences when compared with each other (Fig. 6). The average values result from the heterogeneous cellular movements that are characterized by rapid bursts of migration, which in turn are followed by a period of meandering or rest. The heterogeneous nature of the migration is apparent in the rose plots (Fig. $5 B$ ) and is similar to that reported for somitic migrations (Knight et al., 2000). The rose plots also reveal the highly directed nature of the migrations.

\section{Integrins mediate migration of neural precursors}

Using this in situ system, we assayed the effect of anti-integrin antibodies that inhibit integrin-mediated adhesion on RMS migration. Because slices from P0-P4 mice express $\alpha 1$ - and $\beta 1$-integrins prominently, we assayed the effects of anti- $\alpha 1$ and anti- $\beta 1$ antibodies on migration during these stages. Similarly, we used P8-P16 slices to assay for the role of $\alpha \mathrm{v}$ integrins, because they are strongly expressed at these stages. Function-blocking antibodies for $\beta 8$ and $\beta 6$ are not available, so we were unable to determine the roles of these subunits, and the role of the $\beta 3$ subunit in the adult RMS was not accessible using our conditions. Although our immunohistochemical data show only weak if any PSA expression in the RMS during E14-P5, we also used an anti-PSA antibody (5A5 MAB) to assay for the effect of PSA on RMS migration.

The migration rate of antibody-treated $(20 \mu \mathrm{g} / \mathrm{ml})$ groups is summarized in Figure 6. Antibodies against the corresponding integrins inhibited the migration during the stages at which they are expressed. In P3 slices, for example, $\alpha 1$ - and $\beta 1$-integrins were expressed prominently, and addition of anti- $\alpha 1$ or anti- $\beta 1$ antibodies decreased the migration speed to $\sim 20 \%$ of the controls, which were treated with either anti-trinitrophenol or anti-keyhole limpet hemocyanin antibodies. Anti- $\alpha 1$ and anti- $\beta 3$ antibodies did not affect the migration in the slices from P7 or P10 mice, stages at which neither $\alpha 1$ nor $\beta 3$ integrins are expressed (data not shown).

We applied anti- $\alpha 1$ - and anti- $\alpha \mathrm{v}$-integrin antibodies to the slices from P1 or P5 brains, which express both of these integrins. We also added anti- $\alpha 1$-integrin antibodies to P0 slices, which do 

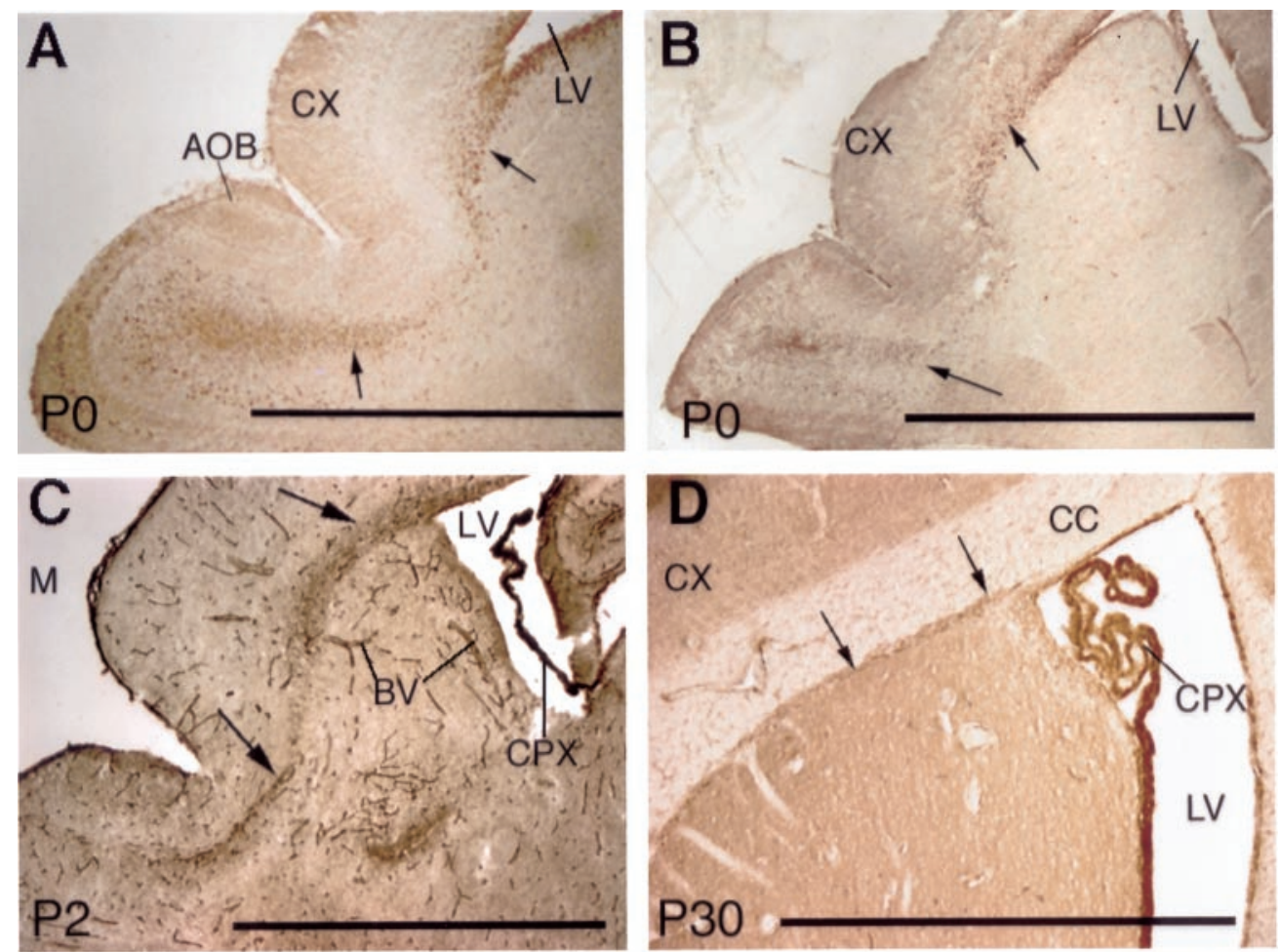

3. Six integrins are differentially expressed in the rostral migratory stream. The $\alpha 1(A)$ and $\beta 8(B)$ integrin subunits are expressed (arrows) from the anterior horn of the subventricular zone to the center of the olfactory bulb from $\mathrm{P} 0$ mice. $C$, The $\beta 1$-integrin subunit is expressed in the RMS (arrows), blood vessels $(B V)$, and the choroid plexus $(C P X)$ of the lateral ventricle $(L V)$ of a $\mathrm{P} 2$ mouse. $D$, The $\alpha \mathrm{v}$-integrin subunit is found in the RMS (arrows) from a P30 mouse. $E$, The $\beta 6$-integrin subunit is expressed in the RMS (arrows) of a P15 mouse. $F$, The $\beta 3$ integrin subunit is observed in P30 rat RMS (arrows). Scale bar, $1 \mathrm{~mm}$. $A O B$, Accessory olfactory bulb; $C C$, corpus callosum; $C X$, cerebral cortex.
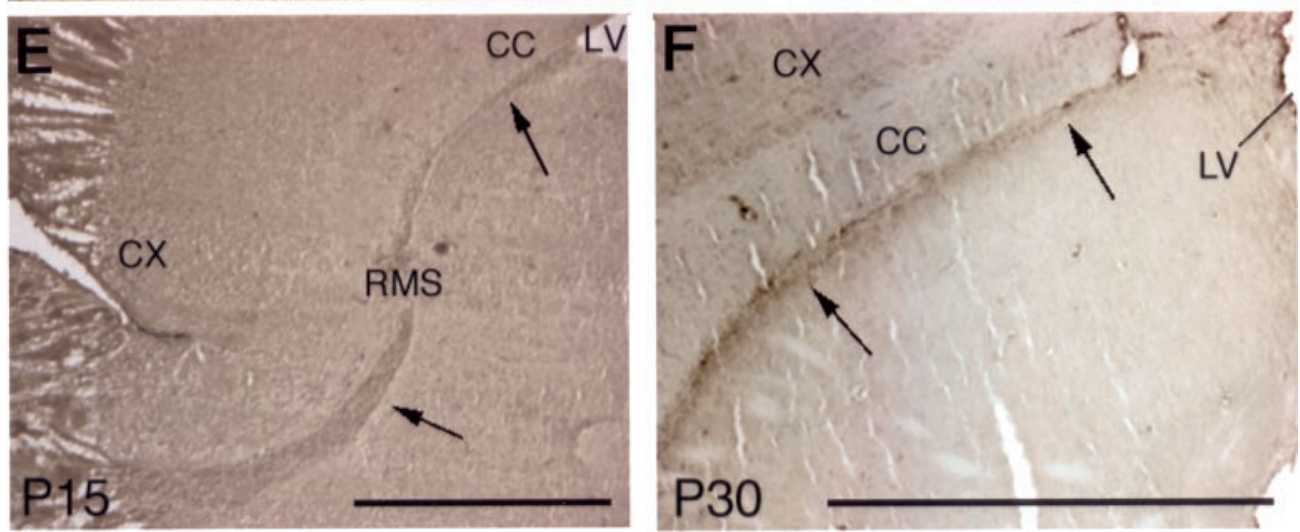

not express the $\alpha \mathrm{v}$-integrin but do express $\alpha 1$. The migration speed in the presence of these antibodies, added either alone or together (P1), decreased, but the antibodies did not show an additive effect when added together (Fig. 6). In P5 slices, $\alpha \mathrm{V}$ - and $\beta 1$-integrins are also expressed prominently. Addition of either anti- $\alpha \mathrm{v}$ or anti- $\beta 1$ decreased the migration to $\sim 22 \%$ of the control levels. Finally, P12 slices were treated with anti- $\alpha \mathrm{v}$ antibodies, and the speed was suppressed to $25 \%$ of the control level; however, control antibodies and anti- $\beta 3$ function-blocking antibodies did not inhibit this migration. The migration rates for all of the controls were similar to those of slices not treated with control antibody (data not shown).

The inhibitory effect of anti-integrin antibodies did not show synergistic effects when two different anti-integrin antibodies were added simultaneously. The inhibitory effect of anti-integrin antibodies was so pronounced that many of labeled cells did not move over the time of measurement, and protrusions were only rarely observed (Fig. 5C,D, Movie 2, available at www. jneurosci.org). These results show that the different integrins expressed in the different stages mediate the migration of the neural precursors in the RMS. The migration speed of RMS cells from a P4 brain slice was not changed by incubation with the anti-PSA MAB (data not shown).

\section{Expression of chemoattractive molecules in the RMS}

In the above experiments, we showed that particular integrins are required for cellular translocation in the RMS. We next asked what molecules contribute to their guided migration toward the olfactory bulb. Our time-lapse recordings showed highly directed migration in the RMS toward the olfactory bulb (Fig. 5A,B). Relatively few cells showed retrograde migration, and when observed, it was transient. Thus, it seems likely that a chemoattractant produced in the olfactory bulb might determine the direction in the RMS. Therefore, we assayed for the presence of receptors for netrins, because they serve guidance roles for growth cones and neuroblasts (Kennedy et al., 1994; Yee et al., 1999).

Using antibodies specific for netrins and the netrin receptors neogenin and DCC, we assayed for their presence in cells residing in the RMS. We observed strong expression for both of them in migrating cells during E15-P5, a time during which there is a massive migration from the SVZa to the olfactory bulb (Fig. $7 A, B)$. In contrast, the adenosine $\mathrm{A} 2 \mathrm{~b}$ receptor, another putative 


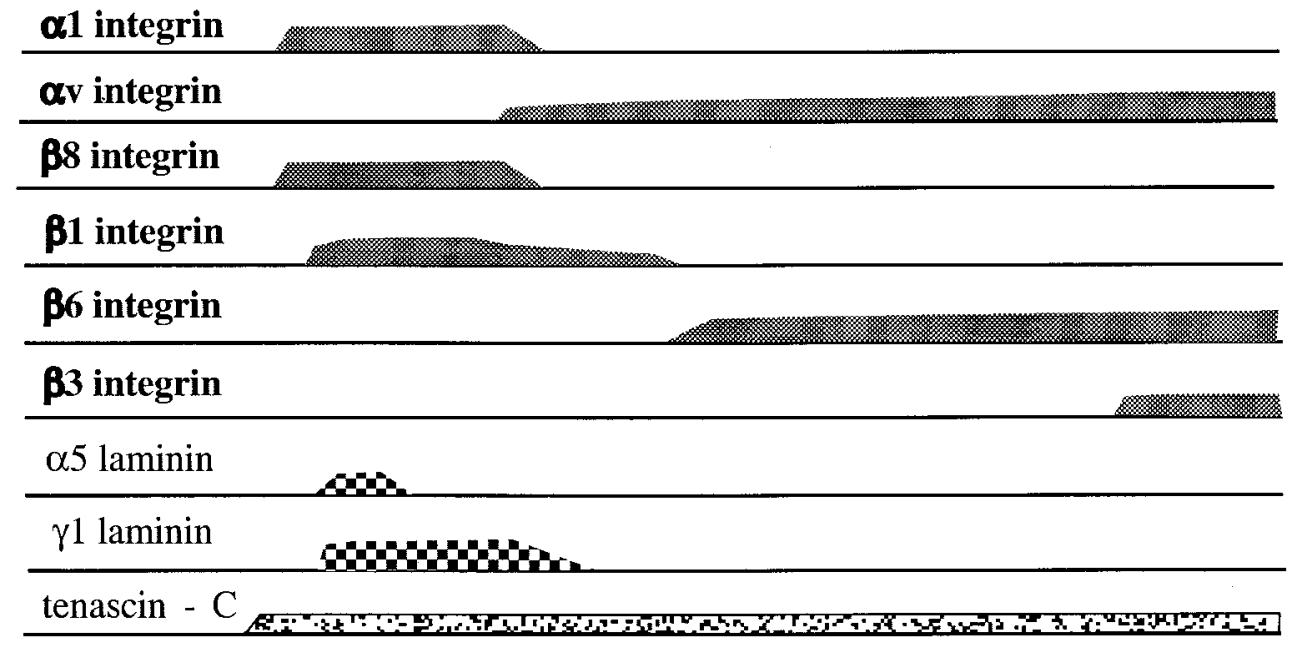

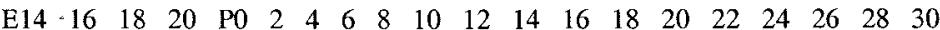

Figure 4. Summary of the stage-specific expression of integrin and laminin subunits in the RMS. Tenascin-C is expressed along the sides of the RMS but not in the RMS itself. netrin-1 receptor (Corset et al., 2000; Stein et al., 2001) was not observed (data not shown). The protein expression of these netrin receptors in this study complements the pattern of mRNA expression reported earlier (Gad et al., 1997). Netrin-1, in contrast to neogenin and DCC, was expressed in the mitral cells (Fig. $7 C, D)$. Netrin-3 mRNA was not expressed (data not shown), and netrin-2 homologs have not been identified in the rodent (Wang et al., 1999). Taken together, these localizations suggest that netrin- 1 produced by the mitral cells may function to produce a chemogradient through the forebrain that attracts migrating cells to the olfactory bulb.

To determine whether netrin- 1 and its receptors contribute to the directed migration of the neural precursors in the RMS, we used the slice system described above to assay the effects of a function-blocking antibody directed against DCC. The addition of an anti-DCC antibody $(5 \mu \mathrm{g} / \mathrm{ml})$ perturbed the migration of RMS cells in the slices. In the presence of antibody, the RMS cells continued to extend single, long processes; however, they were directed not only toward the olfactory bulb, as seen in the controls, but also in a variety of other directions, including toward the SVZa and at right angles to these directions. Thus, the cells appeared to have lost their sense of direction (Fig. 7E,F, Movie 3, available at www.jneurosci.org). This bizarre, nondirected movement of the leading processes was not observed when cells were treated with any of the anti-integrin antibodies.

The nondirected extension of protrusions led to parallel alterations in migration. The cells no longer showed bursts of rapid migration, but instead, they tended to meander without a clear direction (Fig. $7 F$ ). A quantitative analysis of the antibody effects on migration speed showed that the apparent speed was suppressed to $\sim 30 \%$ of the control values $(p<0.01)$ in both the center and end portions of the RMS (Fig. 7G). Together, these data implicate DCC and its related proteins in the directed migration of RMS cells toward the olfactory bulb.

\section{DISCUSSION}

The RMS is a specific route by which neural precursors migrate from the SVZa to the olfactory bulb. In this study, we used a slice preparation to image the migrating cells in the RMS at high temporal and spatial resolution. The overall objective was to reveal the cellular and molecular mechanisms that underlie these migrations. Using this preparation, we made a number of inter- esting observations. They include the differential expression of integrins that selectively mediate migration at different developmental stages, the apparent role of DCC in polarizing protrusions and directing migration, the high polarity of the cells, and the highly directed and restricted nature of the migrations that this polarity produces.

\section{How do they migrate?}

Previous studies on the nature of migrations in the RMS have relied on evaluations of static, morphologic observations (Kishi, 1987; Kishi et al., 1990). Our observations extend these studies by characterizing the nature of the cellular dynamics and pathways of the migrating cells. The cells migrating in the RMS are highly polarized with a single, prominent, and very long-lived protrusion that is polarized along the direction of migration. The cell body moves in the direction of this protrusion, thus resulting in a net translocation. The migrations are also characterized by bursts of rapid migration, which in turn are followed by a "resting" phase. At the end points of migration, the protrusions are less directed, with little net displacement, and the cells begin to differentiate into mature neurons (Movie 4, available at www.jneurosci.org). These migration features are similar to those reported recently for the migration of myogenic precursors from the somite to the limb (Knight et al., 2000). In contrast to this previous study, the RMS migrations are more highly directed, with most cells migrating unidirectionally along a highly restricted pathway toward the olfactory bulb. The migrations from the somite to the limb, in contrast, occur over a broad and less well defined pathway, with cells frequently migrating away from the target followed by a reorientation toward it.

The migration speeds estimated here $(\sim 80-100 \mu \mathrm{m} / \mathrm{hr})$ are comparable with those measured for cells from SVZ explants migrating in Matrigel (122 $\mu \mathrm{m} / \mathrm{hr}$; Wichterle et al., 1997) and glial progenitors migrating in SVZ slices (85-89 $\mu \mathrm{m} / \mathrm{hr}$; Kakita and Goldman, 1999). However, they are faster than those estimated in the adult RMS by tracing $\left[{ }^{3} \mathrm{H}\right]$ thymidine-labeled migrating cells (30 $\mu \mathrm{m} / \mathrm{hr}$; Lois and Alvarez-Buylla, 1994). This difference in migration speeds for cells in the neonates and adults may be attributable to the morphological difference between them or the methods used to compute the speed. The neonatal RMS is thicker than that in the adult and is not enclosed by glial tubes (Kishi, 1987; Kishi et al., 1990). A more likely explanation, 

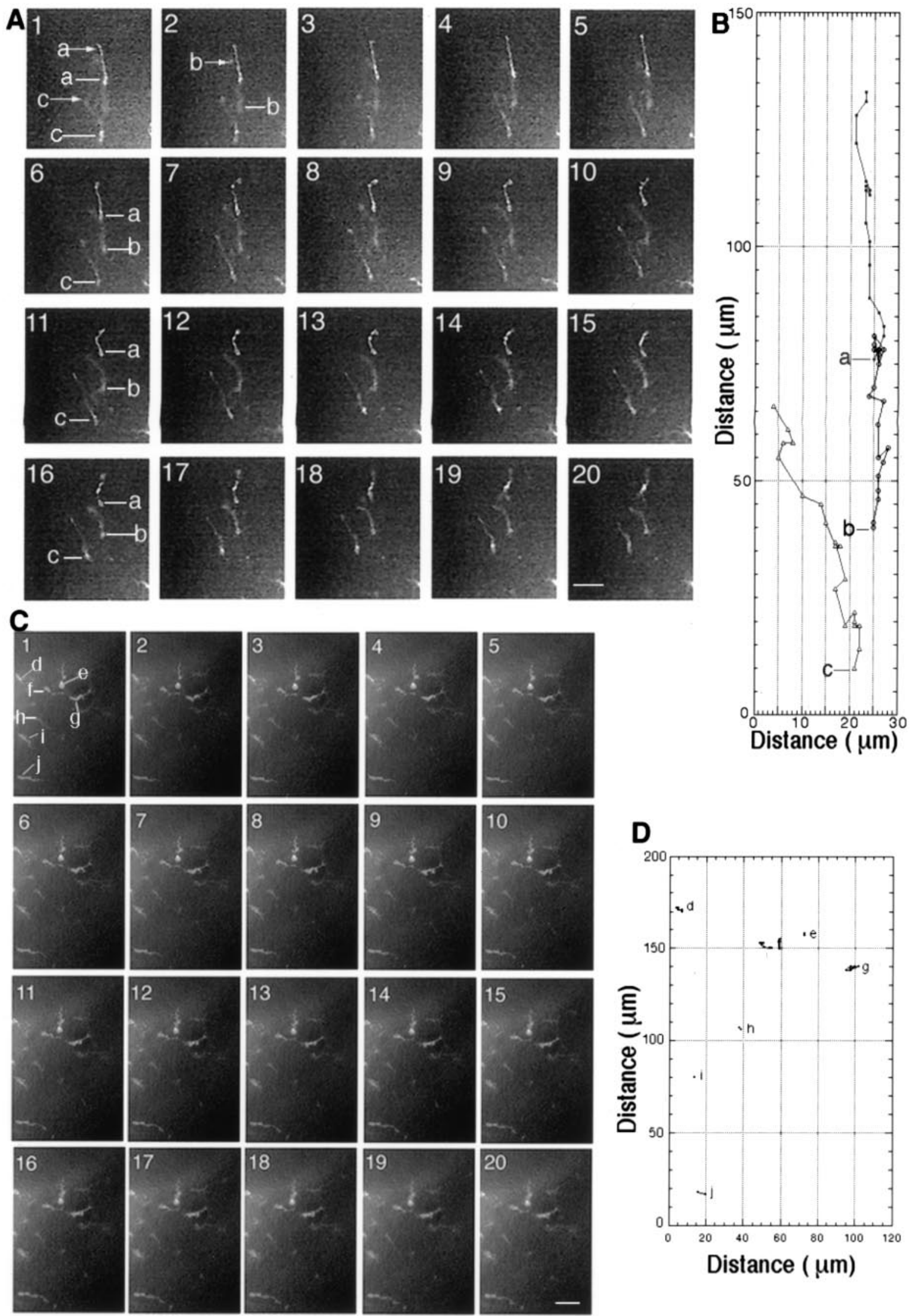

Figure 5. Integrins mediate migration of neural precursors in the RMS. Brain slices from a P12 mouse were labeled with DiI and cultured in CCM1 medium with $5 \%$ horse serum for $5 \mathrm{hr}$ in the presence of either control or anti-integrin antibodies. Three hours after addition of DiI, the migration was confirmed by fluorescence time lapse, and then a control or function-blocking anti- $\alpha$ v-integrin antibody was added for (Figure legend continues.) 


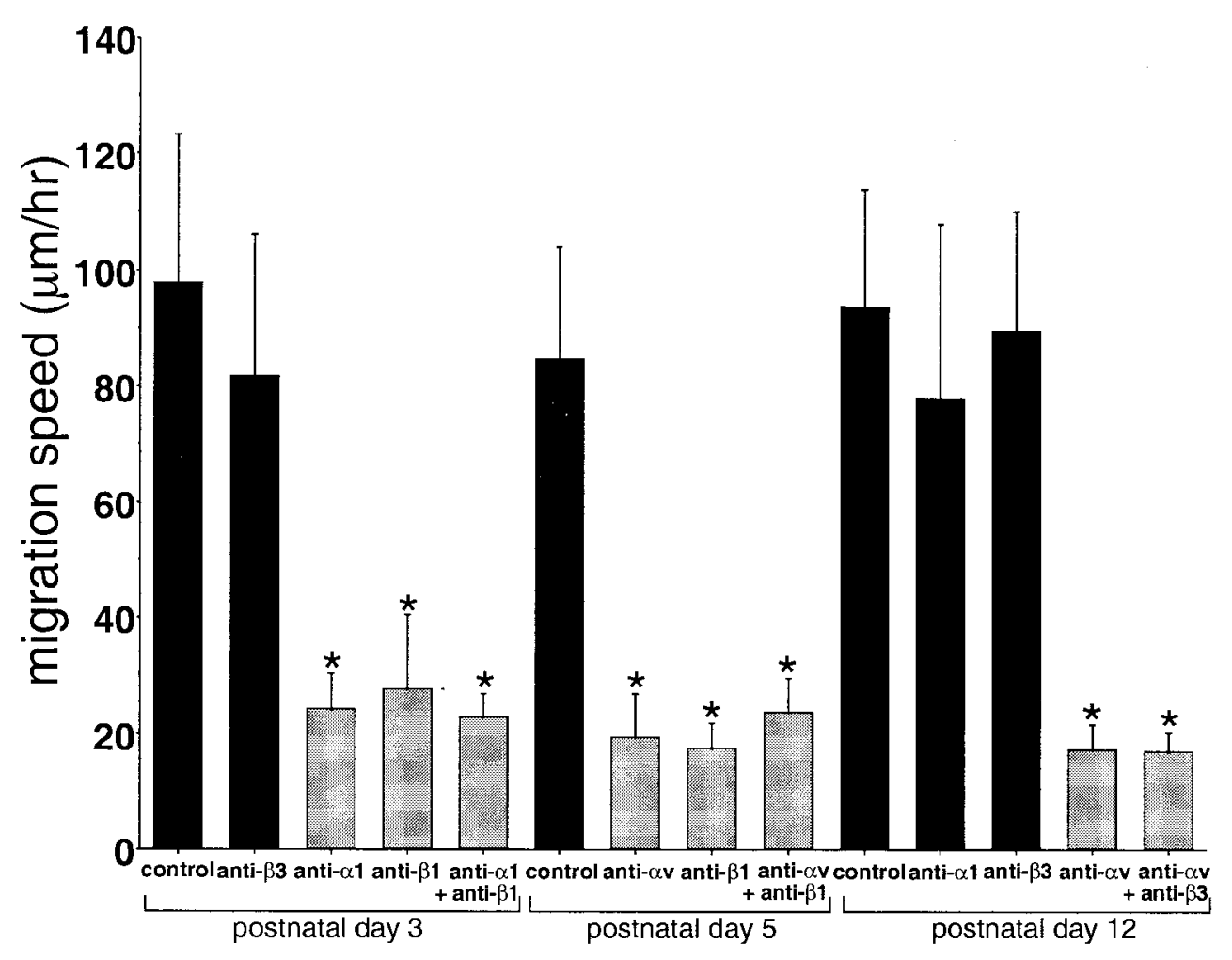

Figure 6. Inhibited migration of RMS cells by function-blocking anti-integrin antibodies. Living brain slices were prepared from P3, P5, and P12 mice, and the cells were labeled with a small crystal of DiI placed on the center of the RMS. The slices were cultured in CCM1 medium supplemented with HEPES and 5\% horse serum. The slices were preincubated with anti-integrin antibodies for $5 \mathrm{hr}$, and the migrating cells were traced by time-lapse recording for $3 \mathrm{hr}$. At P3, when $\alpha 1$ - and $\beta 1$-integrins are expressed, corresponding blocking antibodies reduced the migration speed. Anti- $\beta 3$ antibody did not inhibit the migration significantly. At P5, when $\alpha \mathrm{v}$ - and $\beta 1$-integrins are expressed, antibodies against these integrins inhibited the migration speed. At P12, when $\alpha \mathrm{v}$ integrin is expressed, anti- $\alpha \mathrm{v}$-integrin antibody inhibited the speed as well; however, anti- $\alpha 1$ and $-\beta 3$ antibodies did not inhibit the migration speed significantly, and they are not expressed at this stage. Each value represents the mean \pm SD. Statistical analysis was performed by oneway ANOVA with Scheffé's multiple comparison procedure (significance of $p<$ $0.01)$. The groups with asterisks do not differ from each other, nor do the nonmarked groups, but in all other comparisons, the differences are significant. however, is that the $\left[{ }^{3} \mathrm{H}\right]$ thymidine method is based on the two time points at which the location of the cells is measured, i.e., the injection site of $\left[{ }^{3} \mathrm{H}\right]$ thymidine and the location of migrating cells at the time of killing. The start-stop nature of migration in the RMS would result in significant differences when estimates are made at higher time resolution.

Attempts to identify the molecules that produce guided migrations along the RMS have focused on the role of PSA-N-CAM (Ono et al., 1994; Hu, 2000). The movement of migrating neural precursors is characterized by a "chain migration," especially in the adult (Doetsch and Alvarez-Buylla, 1996; Lois et al., 1996), collagen gel (Hu et al., 1996), or Matrigel (Wichterle et al., 1997), in which the migrating cells move in association with each other (Rousselot et al., 1995). This type of migration is thought to enable cells to use neighboring cells as their substrate for translocation and quick migration. The enzymatic removal of PSA results in the dispersion of chains into single cells both in subventricular zone explants in Matrigel and in adult mice $(\mathrm{Hu}$, 2000). This result is surprising, because PSA is believed to have an anti-adhesive activity attributable to its size and negative charge. Thus, although the current evidence points to a role for PSA-N-CAM in chain migration of neural precursors, its function for the RMS migration remains unclear. In this context, it is interesting that migrating chains are not observed in newborns (Hu, 2000; Pencea et al., 2001), a time at which we detected little
PSA-N-CAM in the RMS. Interestingly, PSA-deficient cells migrate when transplanted into the RMS of wild-type mice, showing that PSA is not required for their migration per se $(\mathrm{Hu}$ et al., 1996). The paucity of PSA expression in the RMS during early developmental stages, a time during which robust migrations also occur, supports this interpretation.

Although PSA-N-CAM is implicated in migrations in the RMS, it is also evident that other molecules contribute. We show here that six integrins are differentially expressed in a developmental, stage-specific manner, and those assayed, e.g., $\alpha 1, \beta 1$, and $\alpha \mathrm{v}$, are necessary for the migration at the developmental stage at which each is expressed. Unfortunately, we were unable to test the functional role of $\beta 3, \beta 6$, and $\beta 8$ subunits because of unavailability of function-blocking antibodies or technical problems in culturing slices from young adults. We also identified ECM proteins that are expressed in RMS and may serve as potential ligands for these integrins. These include two laminin subunits in addition to tenascin-C, whose expression was reported previously (Jankovski and Sotelo, 1996). The concomitant expression of $\alpha 5$ - and $\gamma 1$-laminins during E16-E19 and E16-P6, respectively, and of $\alpha 1$ and $\beta 1$-integrins, also at late gestational stages, suggests that RMS cells use $\alpha 1 \beta 1$-integrin to migrate along laminin- 10 or -11 , or both, because laminin-10 and -11 are composed of $\alpha 5 \beta 1 \gamma 1$ and $\alpha 5 \beta 2 \gamma 1$ subunits, respectively. It is also possible that the cells use a novel laminin, because we were unable to identify either $\beta 1$ - or $\beta 2$ -

\section{$\leftarrow$}

(Figure legend continued.) $5 \mathrm{hr}$, after which migration was recorded over the next $3 \mathrm{hr}$. $A$, Time-lapse sequence of three cells $(a-c)$ in a slice migrating from the SVZ (bottom) toward the olfactory bulb (top) in the presence of a control antibody. The arrow pointing to each cell shows the leading process, and the line shows the cell body. The interval between each image is 5 min. See Movie 1 (available at www.jneurosci.org). $B$, Graphical representation of the migration of the three cells $(a-c)$ in $A$. Each point represents the position of the cell body at 5 min time points. Note the unidirectional pathway and the bursts of rapid migration followed by slower meandering. $C$, Time-lapse sequence of images of seven cells $(d-j)$ in a slice migrating from the SVZ (left) to the olfactory bulb (right) in the presence of an anti- $\alpha v$-integrin antibody. Seven cells $(d-j)$ are marked for reference. See Movie 2 (available at www.jneurosci.org). $D$, Graphical representation of the migration of the seven cells as described in $C$. The olfactory bulb is at the right. Note the inhibited migration. The interval between each image is $5 \mathrm{~min}$. Scale bars, $50 \mu \mathrm{m}$. 

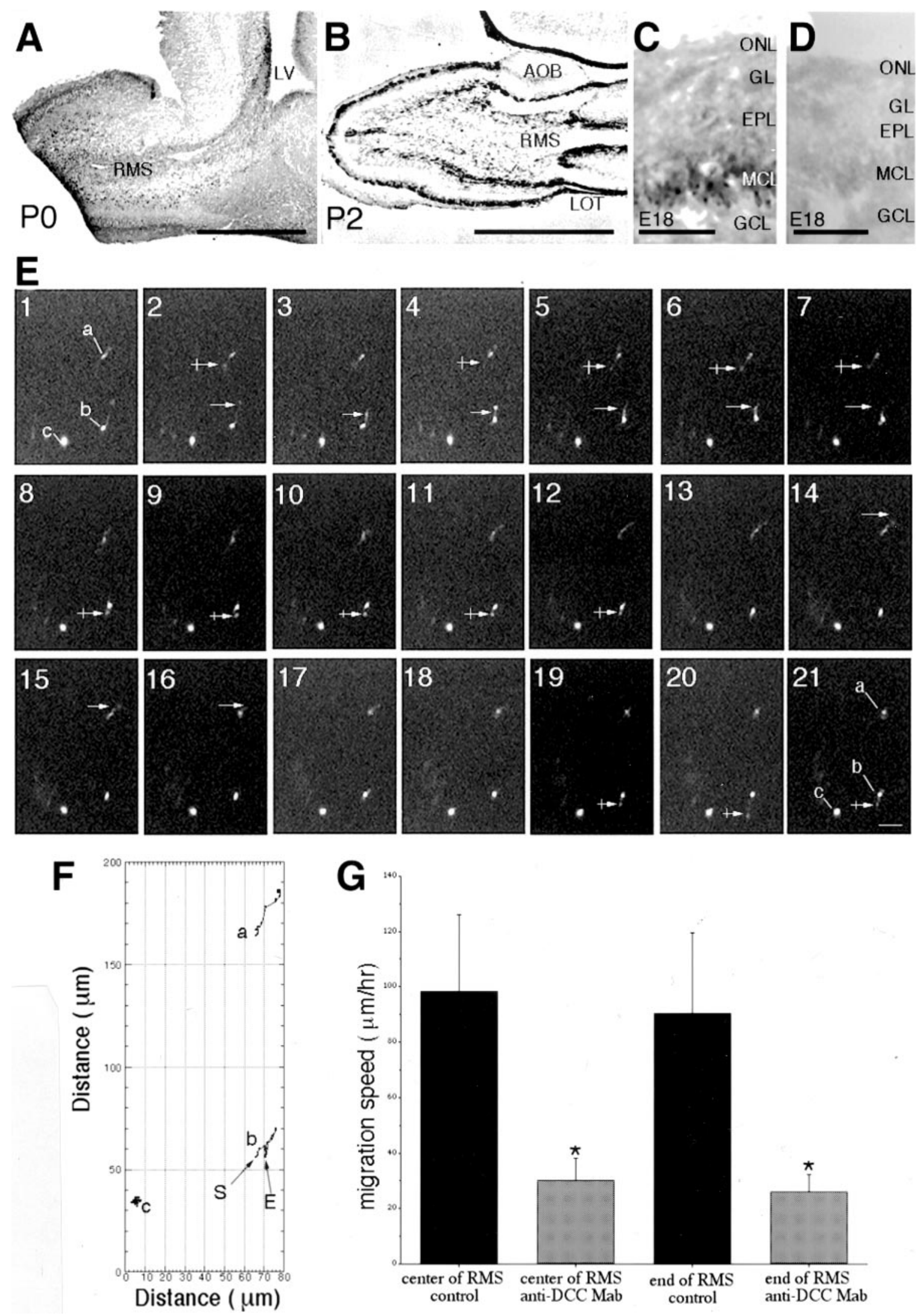

Figure 7. Expression of DCC, neogenin, and netrin-1 and function of DCC in RMS migrations. $A$, Neogenin, a netrin- 1 receptor, immunoreactivity coincides with the contour of RMS beginning at the anterior horn of the lateral ventricle $(L V)$ and ending at the center of the olfactory bulb in a P0 mouse. $B$, The rostral part of the RMS strongly expresses the DCC protein, which is also present in the lateral olfactory tract (LOT) in P2 rats. $A O B$, Accessory olfactory bulb. $C$, Netrin-1 protein is expressed in the basal portion of olfactory mitral cells in the mitral cell layer ( $M C L)$ from an embryonic day 18 mouse. EPL, External plexiform layer; GCL, granule cell layer; GL, glomerular layer; ONL, olfactory nerve layer. (Figure legend continues.) 


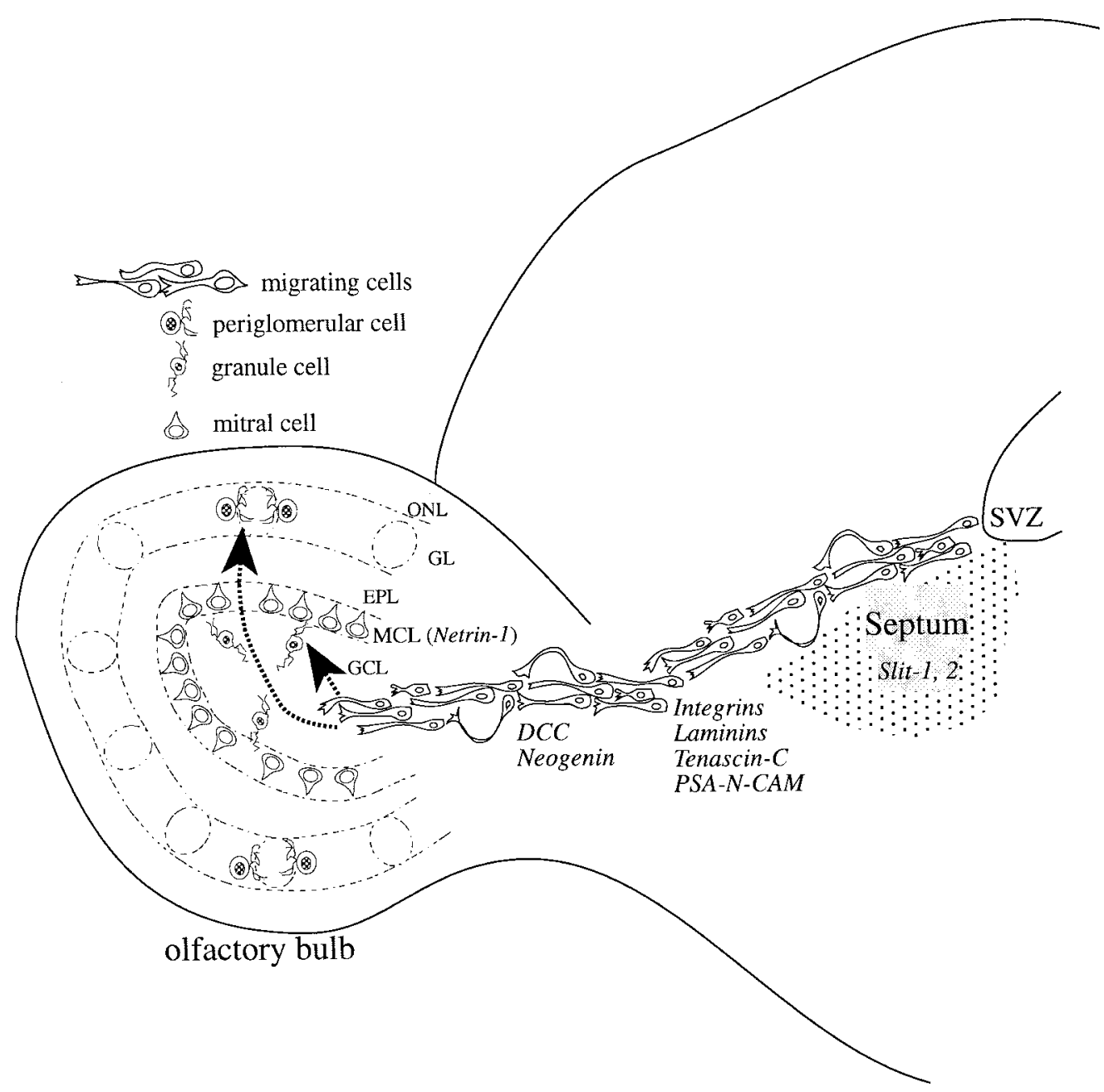

Figure 8. Diagram depicting a working hypothesis for the roles of DCC and netrin and integrin in the migration of neural precursors from the SVZ to the center of the olfactory bulb. Netrin-1 secreted from mitral cells attracts DCC- or neogeninexpressing migrating cells, or both, to the olfactory bulb. Slit proteins from the septum inhibit migration out of the RMS into the septum or surrounding tissues by their repulsive activity. Integrins and laminins provide the traction for the motive force, and PSA-NCAM provides the cellular milieu where the cells can move easily and maintenance of chains. The short arrow indicates the differentiation of neural precursors to granule cells; the long arrow marks the periglomerular cells. EPL, External plexiform layer; $G C L$, granule cell layer; $G L$, glomerular layer; $M C L$, mitral cell layer; $O N L$, olfactory nerve layer.

laminins in the RMS. In any case, laminins are effective substrates for neural migration (Liang and Crutcher, 1992). The resolution of these studies does not reveal how or where the laminin is organized with respect to the migrating cells; however, the punctate deposition is similar to that seen for other ECM proteins. Tenascin-C is reported to be rich in the adult RMS and is proposed to play a role in the migration of RMS (Jankovski and Sotelo, 1996; Thomas et al., 1996). We found that it is also expressed in the RMS of younger mice. Tenascin-C is a ligand for both $\alpha \mathrm{v} \beta 3$ - and $\alpha \mathrm{v} \beta 6$-integrins (Yokosaki et al., 1996) and, therefore, might be one of the ligands recognized by migrating cells. However, mice deficient in tenascin-C do not show any apparent phenotype (Saga et al., 1992), suggesting that other ECM proteins in the RMS might also serve as a functional substrate for migration.

\section{What directs the migration toward the distant olfactory bulb?}

We next asked what directs the migrations on the restricted pathway to the distant olfactory bulb. Previous in vitro studies suggested that chemorepulsive factors from the caudal region of the septum (Hu and Rutishauser, 1996) or choroid plexus ( $\mathrm{Hu}$, 1999), e.g., the Slit proteins, might repel migrating cells ( $\mathrm{Hu}$, 1999; Wu et al., 1999). The presence of Slits from these tissues is thought to produce a gradient of chemorepulsive activity that

\section{$\leftarrow$}

(Figure legend continued.) D, Preabsorbed netrin-1 antibody (control) was prepared by coincubation of antibody and antigen peptide. The absorbed antibody did not show immunoreactivity. $E$, Sequence of 21 time-lapse images of a living slice from a P3 mouse treated with anti-DCC antibody as described in the legend to Figure 5. The olfactory bulb is located at the top. Three migrating cells $(a-c)$ are indicated. Arrows indicate retracting leading process, and crossed arrows indicate processes pointing toward the anterior region of the subventricular zone (bottom). Note that the migration is no longer unidirectional, and that the processes form and retract frequently, which also distinguishes these migrations from those of normal cells shown in Figure 5. The interval between each image is $10 \mathrm{~min}$. See Movie 3 (available at www.jneurosci.org). F, Graphical representation of three migrating cells $(a-c)$ shown in $E$. Cell bodies are tracked as described in Figure 5, and the time interval is $5 \mathrm{~min}$. $S$, Start point; $E$, end point for cell $b$. See Movie 3 (available at www.jneurosci.org). $G$, Inhibited migration of cells by anti-DCC function-blocking antibodies. Living brain slices were prepared from P3 mice, and then the cells were labeled with DiI placed at the center or end of the RMS. The slices were cultured in CCM1 medium with HEPES and $5 \%$ horse serum with or without anti-DCC antibody for $5 \mathrm{hr}$, and the migration was observed by time-lapse recording. Each value represents the mean \pm 1 SD. Statistical analysis was performed by one-way ANOVA with Scheffé's multiple comparison procedure (significance of $p<0.01$ ). The control groups without anti-DCC antibody differ from every other group with anti-DCC. The groups with asterisks do not differ from each other, nor do the nonmarked groups, but in all other comparisons, the differences are significant. In contrast to cell treated with anti-integrin antibodies (Fig. 6), these cells show a larger net translocation. Scale bars: $A, B, 1 \mathrm{~mm}, C, D, 100 \mu \mathrm{m} ; E, 50 \mu \mathrm{m}$. 
prevents the cells from migrating in the caudal direction and thus contributes to directing them toward the olfactory bulb. However, the presence of the Slits does not explain why migrating cells do not migrate into the tissues that do not express them, such as the putamen or corpus callosum that surround the RMS. The glial tubes (Peretto et al., 1997) surrounding RMS in the adult may also help contain the migrating cells so they do not enter regions along the RMS pathway; however, this specific structure is not present in the neonates (Kishi et al., 1990).

We hypothesized, therefore, that chemoattractive factors generated at the olfactory bulb contribute to the directed migration of RMS cells. Our data suggest that DCC and neogenin expressed in the migrating cells appear to recognize a chemogradient of netrin-1 secreted from the mitral cells. However, netrin-1 expression is greatly reduced by $\mathrm{P} 4$, suggesting that another chemoattractant may be expressed at subsequent stages. Yee et al. (1999) reported that netrins can act over relatively long distances. Netrin-1, generated by the floor plate close to the pons, guides the migration of cells from the dorsal rhombencephalic neuroepithelium to basilar pons, a distance of at least $3 \mathrm{~mm}$. Netrin-1, produced by the olfactory mitral cells, might function similarly in guiding perinatal RMS migrations over a distance of $<1.5 \mathrm{~mm}$. The unidirectional migration after $\mathrm{P} 6$ might then be controlled by Slits or unidentified molecules. Although our data suggest a role for netrin-1 in the directional migration, it remains possible that other netrin-like molecules that are recognized by DCC mediate the migration.

In Figure 8, we present a diagram depicting a working model for the roles of DCC and netrin and integrins in the migration of neural precursors from the SVZ to the center of olfactory bulb. Slit proteins from the septum inhibit migration out of the RMS into the septum by their repulsive activity. Integrins and laminins provide the traction for the motive force, and PSA-N-CAM provides the cellular milieu where the cells can move easily and develop chains. The function of tenascin-C, although present in the RMS, remains unclear. On arrival at the center of the olfactory bulb, the neural precursors begin to migrate radially and differentiate into mature neurons. The molecules responsible for this process are not known; however PSA-N-CAM does not appear to be involved (Ono et al., 1994; Hu et al., 1996). Our immunocytochemistry suggests that integrins are also not involved. Thus the molecular mechanisms that mediate radial migration and neuronal differentiation are important targets for future study.

\section{REFERENCES}

Allen E (1912) The cessation of mitosis in the central nervous system of the albino rat. J Comp Neurol 22:547-568.

Altman J (1969) Autoradiographic and histological studies of postnatal neurogenesis. IV. Cell proliferation and migration in the anterior forebrain, with special reference to persisting neurogenesis in the olfactory bulb. J Comp Neurol 137:433-457.

Aufderheide E, Ekblom P (1988) Tenascin during gut development: appearance in the mesenchyme, shift in molecular forms, and dependence on epithelial-mesenchymal interactions. J Cell Biol 107:2341-2349.

Boulder Committee: Angevine JBJ, Bodian D, Coulombre AJ, Edds M VJ, Hamburger V, Jacobson M, Lyser KM, Prestige MC, Sidman RL, Varon S, Weiss PA (1970) Embryonic vertebrate central nervous system: revised terminology. Anat Rec 166:257-261.

Bryans WA (1959) Mitotic activity in the brain of the adult rat. Anat Rec 133:65-73.

Chazal G, Durbec P, Jankovski A, Rougon G, Cremer H (2000) Consequences of neural cell adhesion molecule deficiency on cell migration in the rostral migratory stream of the mouse. J Neurosci 20:1446-1457.

Corset V, Nguyen-Ba-Charvet KT, Forcet C, Moyse E, Chedotal A, Mehlen P (2000) Netrin-1-mediated axon outgrowth and cAMP production requires interaction with adenosine $\mathrm{A} 2 \mathrm{~b}$ receptor. Nature 407:747-750.
Cremer H, Lange R, Christoph A, Plomann M, Vopper G, Roes J, Brown R, Baldwin S, Kraemer P, Scheff S, Barthels D, Rajewsky K, Wille W (1994) Inactivation of the N-CAM gene in mice results in size reduction of the olfactory bulb and deficits in spatial learning. Nature 367:455-459.

Doetsch F, Alvarez-Buylla A (1996) Network of tangential pathways for neuronal migration in adult mammalian brain. Proc Natl Acad Sci USA 93:14895-14900.

Frieser M, Hallmann R, Johansson S, Vestweber D, Goodman SL, Sorokin L' (1996) Mouse polymorphonuclear granulocyte binding to extracellular matrix molecules involves beta 1 integrins. Eur J Immunol 26:3127-3136.

Fukushima Y, Ohnishi T, Arita N, Hayakawa T, Sekiguchi K (1998) Integrin alpha3beta1-mediated interaction with laminin-5 stimulates adhesion, migration and invasion of malignant glioma cells. Int $\mathrm{J}$ Cancer 76:63-72.

Gad JM, Keeling SL, Wilks AF, Tan SS, Cooper HM (1997) The expression patterns of guidance receptors, DCC and Neogenin, are spatially and temporally distinct throughout mouse embryogenesis. Dev Biol 192:258-273.

Hoffman S, Edelman GM (1983) Kinetics of homophilic binding by embryonic and adult forms of the neural cell adhesion molecule. Proc Natl Acad Sci USA 80:5762-5766.

$\mathrm{Hu} \mathrm{H}$ (1999) Chemorepulsion of neuronal migration by Slit2 in the developing mammalian forebrain. Neuron 23:703-711.

$\mathrm{Hu} \mathrm{H}(2000)$ Polysialic acid regulates chain formation by migrating olfactory interneuron precursors. J Neurosci Res 61:480-492.

$\mathrm{Hu}$ H, Rutishauser U (1996) A septum-derived chemorepulsive factor for migrating olfactory interneuron precursors. Neuron 16:933-940.

Hu H, Tomasiewicz H, Magnuson T, Rutishauser U (1996) The role of polysialic acid in migration of olfactory bulb interneuron precursors in the subventricular zone. Neuron 16:735-743.

Hynes RO, Patel R, Miller RH (1986) Migration of neuroblasts along preexisting axonal tracts during prenatal cerebellar development. J Neurosci 6:867-876.

Jankovski A, Sotelo C (1996) Subventricular zone-olfactory bulb migratory pathway in the adult mouse: cellular composition and specificity as determined by heterochronic and heterotopic transplantation. J Comp Neurol 371:376-396.

Kakita A, Goldman JE (1999) Patterns and dynamics of SVZ cell migration in the postnatal forebrain: monitoring living progenitors in slice preparations. Neuron 23:461-472.

Keino-Masu K, Masu M, Hinck L, Leonardo ED, Chan SS, Culotti JG, Tessier-Lavigne M (1996) Deleted in Colorectal Cancer (DCC) encodes a netrin receptor. Cell 87:175-185.

Kennedy TE, Serafini T, de la Torre JR, Tessier-Lavigne M (1994) Netrins are diffusible chemotropic factors for commissural axons in the embryonic spinal cord. Cell 78:425-435.

Kishi K (1987) Golgi studies on the development of granule cells of the rat olfactory bulb with reference to migration in the subependymal layer. J Comp Neurol 258:112-124.

Kishi K, Peng JY, Kakuta S, Murakami K, Kuroda M, Yokota S, Hayakawa S, Kuge T, Asayama T (1990) Migration of bipolar subependymal cells, precursors of the granule cells of the rat olfactory bulb, with reference to the arrangement of the radial glial fibers. Arch Histol Cytol 53:219-226.

Knight B, Laukaitis C, Akhtar N, Hotchin NA, Edlund M, Horwitz AF (2000) Visualizing muscle cell migration in situ. Curr Biol 10:576-585.

Lenter M, Vestweber D (1994) The integrin chains beta 1 and alpha 6 associate with the chaperone calnexin prior to integrin assembly. J Biol Chem 269:12263-12268.

Lenter M, Uhlig H, Hamann A, Jeno P, Imhof B, Vestweber D (1993) A monoclonal antibody against an activation epitope on mouse integrin chain $\beta 1$ blocks adhesion of lymphocytes to the endothelial integrin $\alpha 6 \beta 1$. Proc Natl Acad Sci USA 90:9051-9055.

Liang S, Crutcher KA (1992) Neuronal migration on laminin in vitro. Brain Res Dev Brain Res 66:127-132.

Lois C, Alvarez-Buylla A (1994) Long-distance neuronal migration in the adult mammalian brain. Science 264:1145-1148.

Lois C, Garcia-Verdugo JM, Alvarez-Buylla A (1996) Chain migration of neuronal precursors. Science 271:978-981.

Luskin MB (1993) Restricted proliferation and migration of postnatally generated neurons derived from the forebrain subventricular zone. Neuron 11:173-189.

Madison RD, Zomorodi A, Robinson GA (2000) Netrin-1 and peripheral nerve regeneration in the adult rat. Exp Neurol 161:563-570.

Maxfield SR, Moulder K, Koning F, Elbe A, Stingl G, Coligan JE, Shevach EM, Yokoyama WM (1989) Murine T cells express a cell surface receptor for multiple extracellular matrix proteins. Identification and characterization with monoclonal antibodies. J Exp Med 169:2173-2190.

Mendrick DL, Kelly DM, duMont SS, Sandstrom DJ (1995) Glomerular epithelial and mesangial cells differentially modulate the binding specificities of VLA-1 and VLA-2. Lab Invest 72:367-375. 
Messier B, Leblond CP, Smart I (1958) Presence of DNA synthesis and mitosis in the brain of young adult mice. Exp Cell Res 14:224-226.

Miner JH, Patton BL, Lentz SI, Gilbert DJ, Snider WD, Jenkins NA, Copeland NG, Sanes JR (1997) The laminin alpha chains: expression, developmental transitions, and chromosomal locations of alpha1-5, identification of heterotrimeric laminins $8-11$, and cloning of a novel alpha3 isoform. J Cell Biol 137:685-701.

Murase S (1995) Climbing fibre destruction triggers mossy fibre sprouting in adult rat cerebellum. NeuroReport 6:777-781.

Murase S, Hayashi Y (1996) Expression pattern of integrin $\beta 1$ subunit in Purkinje cells of rat and cerebellar mutant mice. J Comp Neurol 375:225-237.

Murase S, Hayashi Y (1998a) Integrin $\alpha 1$ localization in murine central and peripheral nervous system. J Comp Neurol 395:161-176.

Murase S, Hayashi Y (1998b) Concomitant expression of genes encoding integrin $\alpha v \beta 5$ heterodimer and vitronectin in growing parallel fibers of postnatal rat cerebellum: a possible role as mediators of parallel fiber elongation. J Comp Neurol 397:199-212.

Ono K, Tomasiewicz H, Magnuson T, Rutishauser U (1994) N-CAM mutation inhibits tangential neuronal migration and is phenocopied by enzymatic removal of polysialic acid. Neuron 13:595-609.

Pencea V, Bingaman KD, Freedman LJ, Luskin MB (2001) Neurogenesis in the subventricular zone and rostral migratory stream of the neonatal and adult primate forebrain. Exp Neurol 172:1-16.

Peretto P, Merighi A, Fasolo A, Bonfanti L (1997) Glial tubes in the rostral migratory stream of the adult rat. Brain Res Bull 42:9-21.

Rakic P (1971) Neuron-glia relationship during granule cell migration in developing cerebellar cortex. A Golgi and electronmicroscopic study in Macacus rhesus. J Comp Neurol 141:283-312.

Rougon G, Dubois C, Buckley N, Magnani JL, Zollinger W (1986) A monoclonal antibody against meningococcus group $\mathrm{B}$ polysaccharides distinguishes embryonic from adult N-CAM. J Cell Biol 103:2429-2437.

Rousselot P, Lois C, Alvarez-Buylla A (1995) Embryonic (PSA) N-CAM reveals chains of migrating neuroblasts between the lateral ventricle and the olfactory bulb of adult mice. J Comp Neurol 351:51-61.

Rutishauser U, Watanabe M, Silver J, Troy FA, Vimr ER (1985) Specific alteration of NCAM-mediated cell adhesion by an endoneuraminidase. J Cell Biol 101:1842-1849.

Sadoul R, Hirn M, Deagostini-Bazin H, Rougon G, Goridis C (1983) Adult and embryonic mouse neural cell adhesion molecules have different binding properties. Nature 304:347-349.

Saga Y, Yagi T, Ikawa Y, Sakakura T, Aizawa S (1992) Mice develop normally without tenascin. Genes Dev 6:1821-1831.

Stein E, Zou Y, Poo M, Tessier-Lavigne M (2001) Binding of DCC by netrin-1 to mediate axon guidance independent of adenosine $A 2 B$ receptor activation. Science 291:1976-1982.

Stoppini L, Buchs PA, Muller D (1991) A simple method for organotypic cultures of nervous tissue. J Neurosci Methods 37:173-182.

Thomas LB, Gates MA, Steindler DA (1996) Young neurons from the adult subependymal zone proliferate and migrate along an astrocyte, extracellular matrix-rich pathway. Glia 17:1-14.

Tomasiewicz H, Ono K, Yee D, Thompson C, Goridis C, Rutishauser U, Magnuson T (1993) Genetic deletion of a neural cell adhesion molecule variant (N-CAM-180) produces distinct defects in the central nervous system. Neuron 11:1163-1174.

Wang $\mathrm{H}$, Copeland NG, Gilbert DJ, Jenkins NA, Tessier-Lavigne M (1999) Netrin-3, a mouse homolog of human NTN2L, is highly expressed in sensory ganglia and shows differential binding to netrin receptors. J Neurosci 19:4938-4947.

Wichterle H, Garcia-Verdugo JM, Alvarez-Buylla A (1997) Direct evidence for homotypic, glia-independent neuronal migration. Neuron 18:779-791.

Wu W, Wong K, Chen J, Jiang Z, Dupuis S, Wu JY, Rao Y (1999) Directional guidance of neuronal migration in the olfactory system by the protein Slit. Nature 400:331-336.

Yee KT, Simon HH, Tessier-Lavigne M, O'Leary DM (1999) Extension of long leading processes and neuronal migration in the mammalian brain directed by the chemoattractant netrin-1. Neuron 24:607-622.

Yokosaki Y, Monis H, Chen J, Sheppard D (1996) Differential effects of the integrins alpha9beta1, alphavbeta3, and alphavbeta6 on cell proliferative responses to tenascin. Roles of the beta subunit extracellular and cytoplasmic domains. J Biol Chem 271:24144-24150. 